\title{
Applications of the continuously rotating detonation to combustion engines at the Lukasiewicz - Institute of Aviation
}

\section{ARTICLE INFO}

Received: 10 November 2021 Revised: 20 December 2021 Accepted: 29 December 2021 Available online: 2 January 2022
In the paper short information about advantages of introduction of detonation combustion to propulsion systems is briefly discussed and then research conducted at the Lukasiewicz - Institute of Aviation on development of the rotating detonation engines (RDE) is presented. Special attention is focused on continuously rotating detonation (CRD), since it offers significant advantages over pulsed detonation (PD). Basic aspects of initiation and stability of the CRD are discussed. Examples of applications of the CRD to gas turbine and rocket engines are presented and a combine cycle engine utilizing CRD are also evaluated. The world's first rocket flight powered by liquid propellant detonation engine is also described.

Key words: detonation, detonation engines, $R D E$, experimental rocket

This is an open access article under the CC BY license (http://creativecommons.org/licenses/BY/4.0/)

\section{Introduction}

The first idea concerning possibility of increasing efficiency of engines due to applications of detonative combustion came from Zeldovich [1], but at that time no one was interested in this idea. At the end of fifties and beginning of sixties of the last century continuously rotating spinning detonation was discovered in Institute of Hydrodynamics of the Soviet Academy of Sciences in Novosibirsk and was described in a few publications [2-4]. At the same time at the University of Michigan Nicholls et al. [5] was tested laboratory model of the Pulsed Detonation Engine (PDE) and a few years later research were undertaken on applications of CRD to rocket engines, but unfortunately at that time they been unable to succeed. Adamson et al. was only able to perform theoretical analysis of CRD structure in combustion chamber of rocket engines [6, 7]. Since that time research on application of the CRD to propulsion system was abounded for many years. Research on application of detonation to the PDE were reinitiated at the end of the last century by Edelman et al.[8, 9], and dominated the research on the applications of detonation to propulsion system up to beginning of twenty first century. More information about such research could be also find on survey paper devoted to the PDE [10-12]. Only at the end of last century and the beginning of this one research on the possible application of the CRD to propulsion system was nearly simultaneously reinitiated in Russia, France, Poland and Japan then exponential interest on such system was significantly increased [13-15]. Since that time many initiatives were undertaken to better understand nature of detonative propulsion and to develop engines based on detonation. The rate of increase publications devoted to RDE at the beginning of XXI century is shown in Fig. 1.

The aim of the article is to discuss the latest works related to the issue of rotating detonation carried out at Łukasiewicz - Institute Aviation.

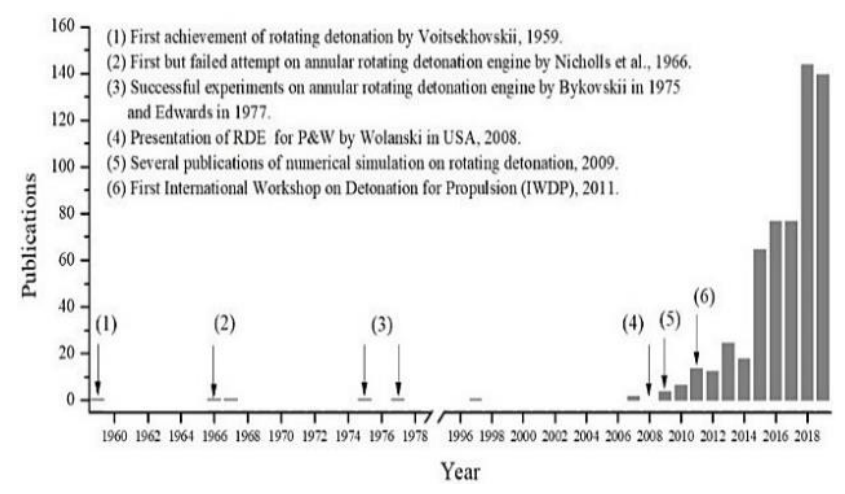

Fig. 1. Graphical illustration of numbers of publication related to RDE research from time of first experimental obtainment of the continuously rotating detonation up to recent time (2019) (Courtesy of Bing Wang) [16]

\section{Detonation versus deflagration}

It is well known that combustion of gaseous mixtures can happen at two different modes: deflagration and detonation. During deflagration, combustion is usually slow and flame velocity is always subsonic, while for detonative mode flame propagate with supersonic velocity. For deflagrative combustion pressure at the end of combustion always decrease, while for detonative combustion is always increased. Typically for detonation of fuel air mixtures pressure can be increased about 15 times, while detonation of fuels with gaseous oxygen can increase more than 30 times. Details of the detonative combustion of gaseous mixtures can be found in many publications [14-17]. Because combustion of the same mixture can result in very different parameters depending on the deflagrative or detonative mode, application of different modes of combustion to a propulsion system can also result in different performance of the propulsion system. It was shown already in many publications that application of detonative combustion to engines can result in significant increase of engine efficiency. For example, if detonative combustion is applied to the turbojet engine, theoretical engine efficiency could be even increased more than $30 \%$ [14], but even if in reality 
this efficiency will be increased only by $10 \%$, the fuel saving for one year will result in many billions of dollars, as well as significant reduction of $\mathrm{CO}_{2}$ emission.

\section{Detonative engines}

Detonative combustion could be applied in three different configurations of engines: Standing Detonation Engines, Pulsed Detonation Engines (PDE) and Rotating Detonation Engines (RDE). Application of detonation combustion for Standing Detonation Engines was already proposed in fifties of the last century $[5,25,26]$, but beside theoretical analyses they have been extensively tested, since for a such engine operation speed is limited to the velocity close to the theoretical detonation velocity. Such engine could only operate in flight velocity higher than theoretical detonation velocity, but not too much higher, since then external drag of the engine could overcome thrust produced by the engine. Only realistic applications of the detonation to propulsion system are PDE and RDE engines configurations.

\subsection{Research on the PDE}

Principles of operation of the PDE is very simple. Long tube is filled with gaseous fuel (hydrogen) and air. When mixture is form, combustion is initiated by electrical spark. Composition of the mixture and dimension of the tube should allow fast transition into detonation. During detonative combustion of the mixture, very high pressure is generated and thrust is produced. Then after completion of detonation high pressure combustion products leaves tube and produce low pressure, due to expansion, and pressure in the tube drops below the surrounding pressure. This initiates flow of air into the tube and mix it with injected fuel. After mixture is created, ignition is again initiated and the new cycle begins. Detailed descriptions of such cycle can be found in $[14,15]$. First pulsed detonation engine was build and successfully tested at the University of Michigan (Fig. 2) [5], but at that time there were no interests in development of such propulsion system, so research on PDE were abandoned and reinitiated at the end of XX century [8-10]. Many PDE were developed in different laboratory [11-21], mostly in USA, Russia and China, and at the beginning of XXI century even experimental aircraft powered by PDE was built and tested by a team from the US Air Force Research Laboratory [12].

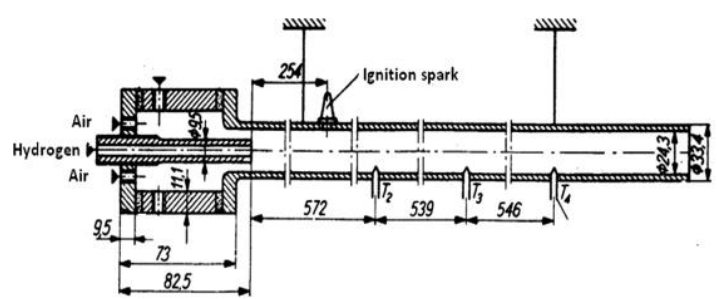

Fig. 2. Schematic diagram of the first PDE developed at the University of Michigan [5, 14]

The engine for this aircraft (Fig. 3) consisted of four tubes producing pulse detonations at a frequency of $80 \mathrm{~Hz}$, creating thrust of 890 newton. Only one test of such aircraft was conducted during which the PDE operated only for $10 \mathrm{~s}$ at the altitude of $30 \mathrm{~m}$. Due to a very high noise (195-200
$\mathrm{dB}$ ) and very high vibration, produced by the PDE, test of such propulsion system were terminated and this aircraft is now in Air Force Museum at Wright-Patterson Air Force Base - Fig. 3.

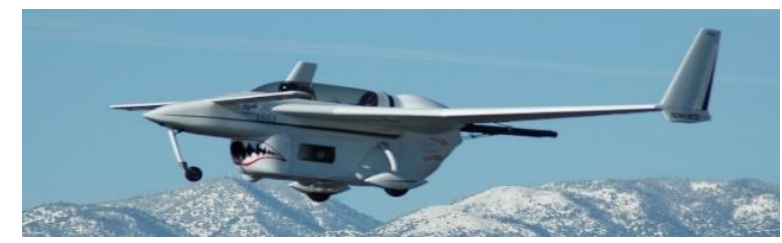

Fig. 3. The first and only flight of aircraft powered by PDE on $31^{\text {st }}$ of January 2008 at the US Air Force Mojave Air and Space Port [23]

Similar thing happened to a gas turbine with pulsed detonation combustion chamber which has been developing by GE [22]. Even the system was working at the laboratory conditions, pulsating character of detonation chamber created to many problems which have to be solved before application of such system to practical use. Termination of this project was also effected by rapid development of application of continuously rotating detonation to propulsion systems.

\subsection{Research of the RDE}

Continuously rotating detonation, which was first discovered nearly 60 years ago by Russian scientists in Novosibirsk [2, 3], is now commonly used in developing of the $\mathrm{RDE}$ as well as in chambers of gas turbine, not only in aircraft engines but it also could be used in stationary power system installations. Typical scheme of annular detonation chamber is shown in Fig.4.

Air or oxidizer is supply trough narrow entry slit and fuel is injected trough many tiny holes which are located around one wall of the detonation chamber.

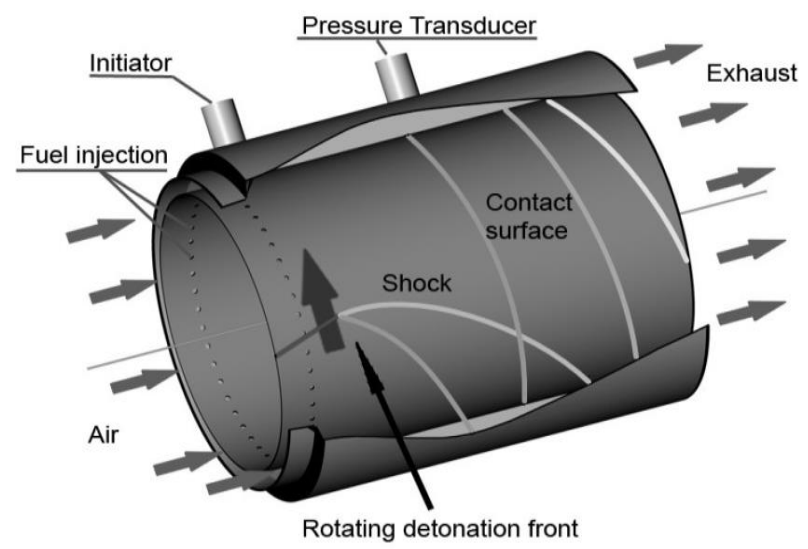

Fig. 4. Schematic diagram of annular detonation chamber [14]

Such way of oxidizer and fuel supply is necessary to ensure quick mixing of both components to form nearly uniform mixture which can support detonation. In the chamber also initiator is installed to initiate detonation as well as ports for measurement of detonation parameters. The height of the annulus channel should be also larger than critical dimension, which will allow detonation to propagate. So for each mixture critical dimensions, which allow detonation to propagate depends on mixture parameters, such as mixture composition, initial pressure in the chamber and rate of 
mixture supply to the chamber [29-31]. If all necessary conditions of mixture supply are fulfilled and sufficient energy of initiation is released, then in a short time a stable continuously rotating detonation in the chamber will be achieved. Pressure record of stable detonation in the annular chamber is shown in Fig.5. and numerically calculated structure of stable detonation is shown in Fig.6. In this case two detonation waves are propagating in the same direction, but generally many different conditions of waves propagation in detonation chambers are observed.

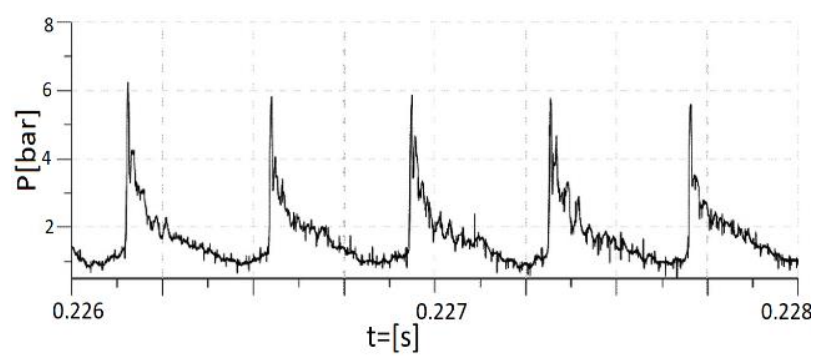

Fig. 5. Pressure variations of stable detonation in the annular chamber [14]

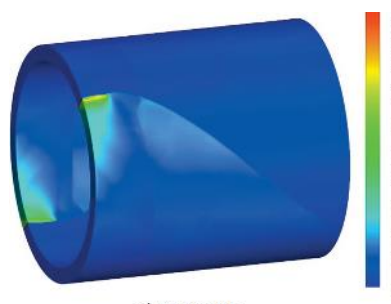

a) Pressure

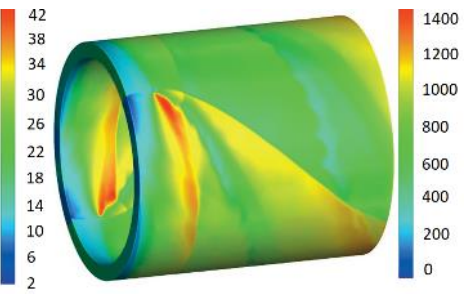

b) Axial velocity
Fig. 6. Numerically calculated 3-D flowfield of the two waves stable rotating detonation structure in annular detonation chamber [32]

Stabilization of direction of rotating detonation wave was studied by Kawalec et al. [33], which show that direction of rotation could be controlled by small eccentricity synchronized with selected initiation place.

CRD could be initiated also in different shape of the chambers, such as presented by Bykovskii et al. - Fig. 7. [34], but also con-shaped and successfully tested by Kawalec et al. [33]. There are also other geometries already tested, such as cylindrical chamber with short insert and hollow

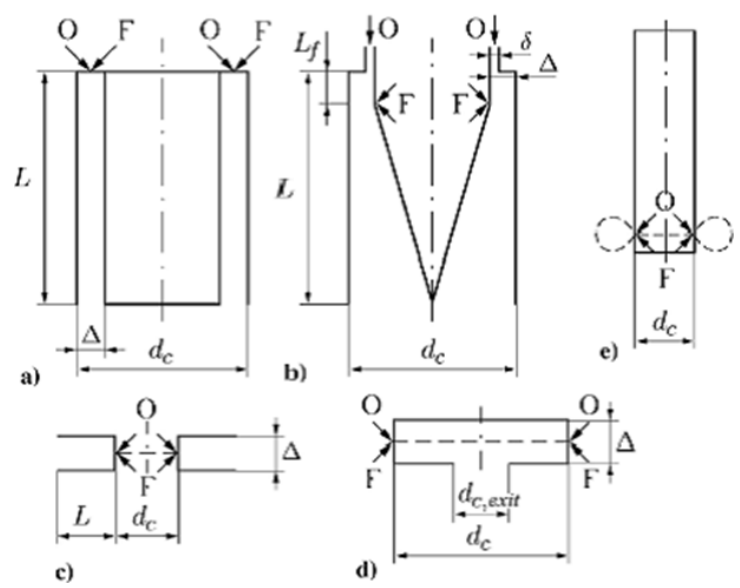

Fig. 7. Geometries of detonation chambers tested by Bykovskii et al. a) annular chamber, b) partially annular with inner cone, c) open space inner disc, d) disc chamber, e) open space external disc [34] chamber and disk-shaped connected to the nozzle and other [24-27, 35-41].

\section{Research on application of the CRD to propulsion systems at the Lukasiewicz - Institute of Aviation}

Research on the application of the CRD to propulsion system is carried out at the Institute of Aviation for more than 10 years. During that time a few systems with CRD were developed, such as GTD-350 with detonation chamber, special system of mixture preparation which guarantee stable operation in annular/cylindrical chambers working on liquid fuels, control of directions of rotating of detonation wave in the annular chamber, development of disk and con shaped detonation chambers working on liquid propellants with regenerative cooling and designing and launching of first in the world rocket powered by disk-shaped detonation liquid rocket engine. We will briefly mention first two systems, which are already described in the publications [27, 42-43], but more details will be presented on the development of rocket and rocket-ramjet engine as well as a very successful flight of experimental rocket powered by disk-shaped liquid rocket engine utilizing CRD.

\subsection{Research on applications of the CRD to the air-breathing propulsion}

During 2010-2015 development of gas turbine engine with detonation combustion chamber was carried out at our Institute under the project UDA-POIG.01.03.01-14-071 "Gas turbine with detonative combustion chamber" supported by EU and Ministry of Regional Development of Poland. During this project many problems were studied, such as: mixture formation, development of proper geometry of detonation chamber, detonation initiation as well as the operation of this engine with detonation chamber. Engine was tested on the following fuels: Jet-A, Jet-A with additions of gaseous hydrogen and on gaseous hydrogen only. It was found that engine operating on gaseous hydrogen demonstrated increased thermal efficiency by 5-7\%, as compared to the based engine operating on conventional fuel with the classical combustion chamber. Details of this research can be found in [27, 42, 43]. It must be also added that recent initiatives of the Airbus company to develop aircraft powered by hydrogen fuel will also open a way for the introduction of turbojet engine with detonative combustion chamber, since it was already proved, much higher efficiency can be achieved with applications of the turbojet engines utilizing CRD in engine's combustion chamber $[44,45]$.

Another research which was continued, after the above project was completed, was focused on development of the new system of preparation of liquid jet fuels for combustion in annular detonation chamber. Development of such system for air-breathing engines utilizing CRD will improving engine efficiency and thus results in fuel saving. This research concerns development of system which could allow preparation of liquid fuel-air mixture which can support stable CRD in annular chamber [24]. Schematic diagram of such system is presented in Fig. 8a and typical recorded pressure signals of detonation in Fig. 8b. 


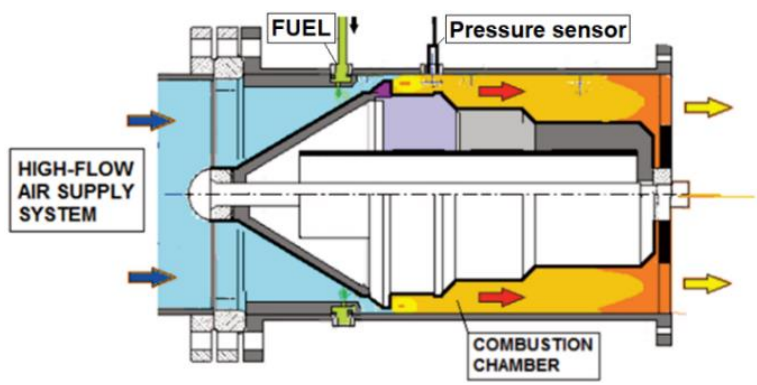

b)

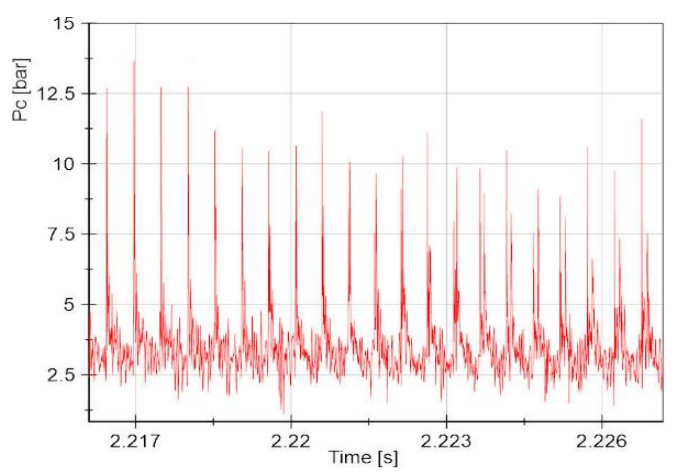

Fig. 8. Schematic diagram of the annular detonation chamber (a) and recorded pressure of the CRD for Jat-A - air mixture (b)

\subsection{Research on applications of the CRD to rocket engines}

For the last few years in the Institute research on application of the CRD to rockets engines were initiated. Initiation of those research came from US Air Force Research Laboratory with granted the project related to development of the methods of wave direction control in rocket engine. The main goal of this research was to find effective way of control direction of wave rotation in detonation engine. Tests were carried out for gaseous mixtures such as hydrogen-air and methane-oxygen. A few different methods were tested to control direction of wave motion, but it was found that applying small eccentricity such control could be achieved (see Fig. 9).

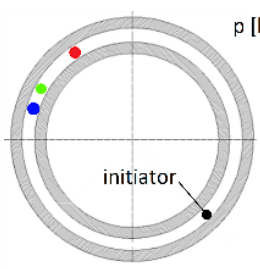

a)

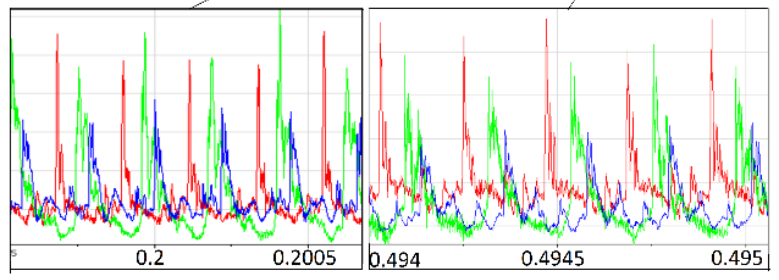

c)

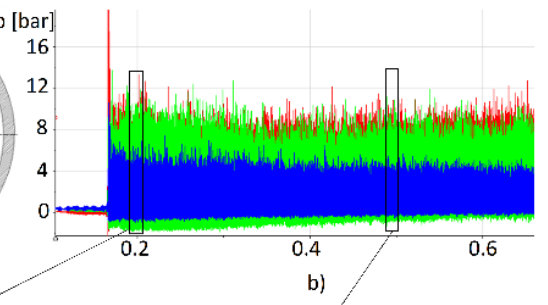

d)
Fig. 9. The example of an experiment with the use of the initiator close to the small eccentricity, a) schematic of the cross section of the annular detonation chamber with colored points of located pressure transducers and indication of the position of the initiator, b) recorded pressure by the three transducers, c, d) enlarged randomly selected pressure records. More detailed description of this research can be found in [33]
Another research was directed in development of the liquid propellant rocket engine which utilize CRD. As a propellants liquid propane $\left(\mathrm{C}_{3} \mathrm{H}_{8}\right)$ and liquid nitrous oxide $\left(\mathrm{N}_{2} \mathrm{O}\right)$ were used. The tests were carried out in an engines with an annular, a disc-shaped and a cone-shaped detonation chambers. Pictures of the tested engines can be seen in Fig. 10. The specific impulse obtained of the disk-shaped engine was equal to $1600 \mathrm{~m} / \mathrm{s}$, about $80 \%$ of theoretical value. For con-shaped engine with regenerative cooling, the specific impulse increased to $2005 \mathrm{~m} / \mathrm{s}$.

a)

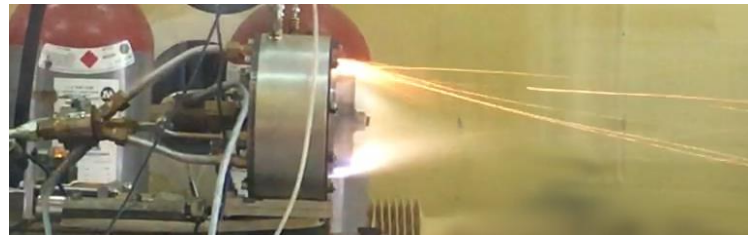

b)

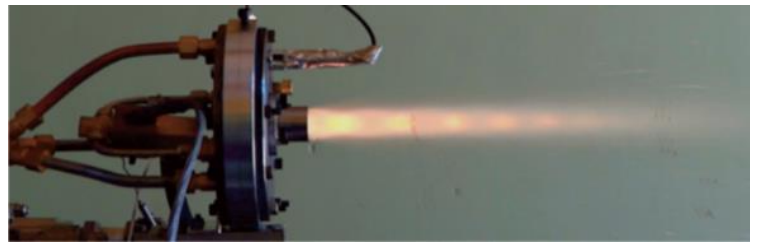

c)

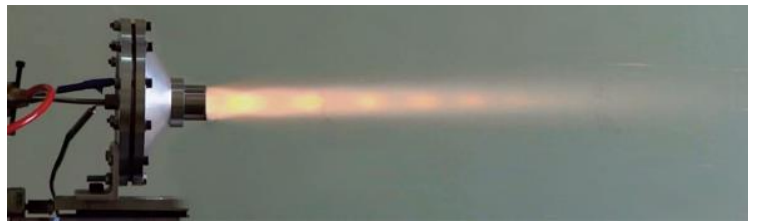

Fig. 10. Rocket RDE: with annular cylindrical detonation chamber (a), with disc-shaped detonation chamber (b) and with con-shaped detonation chamber (c) [21]

Also the first research on possibility of using combined cycle rotating detonation in rocket-ramjet engine was conducted. For this case rocket engine was operating on fuel rich conditions. This allow afterburning of hot, not completely reacted products from the rocket engine, which was burning with air passing through ramjets subsonic combustion chamber and generate extra trust. It was shown that such combined cycle Rocket-Ramjet can, in optimum operating condition exhibit $25 \%$ increase of efficiency as compare to rocket itself operating in similar conditions. Picture of the rocket-ramjet engine during test at the experimental stand at our Institute is shown in Fig. 11.

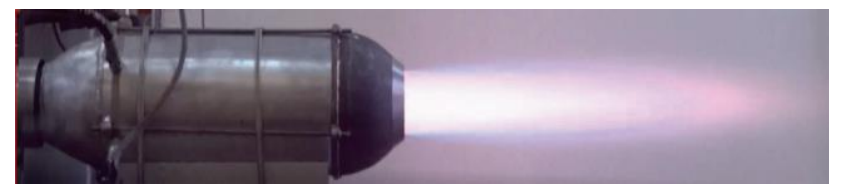

Fig. 11. Test of the rocket-ramjet engine at the experimental test stand at Łukasiewicz - Institute of Aviation [33]

\subsection{Development of experimental rocket powered by liquid fueled rocket engine utilizing CRD}

Since the liquid rocket engines utilizing CRD were developed at our Institute, the next logical step was to apply one of the engine to propel the experimental rocket. The cone-shaped engine was chosen as the propulsion system for the rocket. Before installing it on the rocket, special 
validation tests were carried out in the laboratory. As it was already mentioned, as propellants liquid Propane and liquid Nitrous Oxide were used. To ensure a few seconds work, engine was design in such a way that both liquid components were used for cooling engine's walls. Engine was first tested at the research stand in horizontal conditions, but after completion of such tests engine was integrated with the rocket and was also tested in vertical condition and with supply of both propellants from the rocket tanks. Both propellant tanks were pressurized before experiment by gaseous helium. This guaranteed nearly constant rate of feeding of engine with both propellants. Only after such successful static tests of the engine integrated with the rocket, the experiments was conducted at the military test range outside Warsaw at WITU in Zielonka On September 15, 2021 at 9:29 rocket was successfully launched and reached the altitude of $450 \mathrm{~m}$.

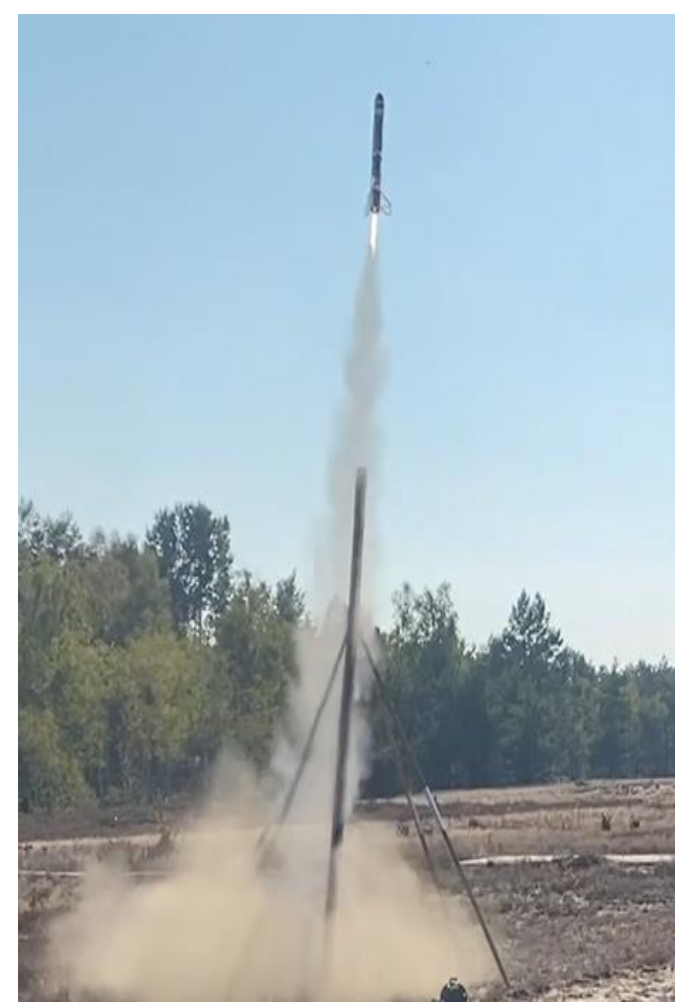

Fig.12. Launch of the experimental rocket power by liquid fueled RDE which utilize CRD at the military test range in WITU, Zielonka
Picture of the liftoff of the rocket is shown in Fig.12. The rocket engine, according to the plan, worked for $3.2 \mathrm{~s}$, accelerating the rocket to a speed of $93 \mathrm{~m} / \mathrm{s}$, which allowed the rocket to reach an altitude of $450 \mathrm{~m}$. It was the world's first attempt to use a detonation engine powered by liquid propellants (liquid propane and liquid nitrous oxide) to propel a rocket. It was also world's first detonation engine that achieved flight under its own power.

\section{Conclusions}

Łukasiewicz - Institute of Aviation is engaged in research on application of CRD for different propulsion system for more the 10 years. The most important achievements in this field are:

1. Development of the detonation combustion chamber for GTD-350 engine, which working on gaseous hydrogen fuel shows improvements of engines efficiency by 5 $7 \%$ as compare to base engine supply by Jet-A fuel.

2. Development of effective mixture preparation system which allow to achieve stable sustainable operation of $\mathrm{CRD}$ in the annular detonation chamber for the Jet-A air mixture.

3. Development of effective way of control of detonation wave rotation in the model of rocket engine combustion chamber.

4. Development of the liquid propellant disc-shaped and cone-shaped rocket engines with regenerative cooling by liquid propellants.

5. Development the combine cycle rocket-ramjet engine working on liquid propellants.

6. Development of the experimental rocket which utilized RDE cooled by liquid propellants and perform its successful flight test. It's the world's first detonation engine that achieved flight under its own power.

Due to this activities and achievements Institute will be more engaged in further development of this very promising research and hopefully will widen international cooperation in this field.

\section{Acknowledgments}

Authors would like to thank Direction of the Łukasiewicz - Institute of Aviation for the continuous support of the research of application of the CRD to propulsion systems. Also authors thanks WITU in Zielonka for providing test range for rocket launch.

\section{Bibliography}

[1] ZELDOVICH, Y.B. On the use of detonative combustion in power engineering. Journal of Technical Physics. 1940, 10, 1453-1461.

[2] VOITSEKOVSKII, B.B. et al. Work of the Siberian Division of the Academy of Sciences of SSSR, 1958, 9.

[3] VOITSEKHOVSKII, B.V., MITROFANOV, V.V., TOPCHIYAN, M.E. Structure of the detonation front in gases. Izdatielstvo SO AN SSSR. Novosibirsk 1963 (in Russian).

[4] SOLOUKHIN, R.I. Shock waves and detonations in gases. Mono Book Corp. Baltimore 1966.

[5] NICHOLLS, J.A., WILKINSON, H.R., MORRISON, R.B. Intermittent detonation as a thrust-producing mechanism. Jet Propulsion. May 1957.
[6] ADAMSON, T.C., OLSSON, G.R. Performance analysis of a rotating detonation wave rocket engine. Acta Astronautica. 1967, 13, 405-415.

[7] SHEN, P.I.-W., ADAMSON, T.C. Theoretical analysis of a rotating two-phase detonation in liquid rocket motors. Acta Astronautica. 1972, 17, 715-728.

[8] EIDELMAN, S., GROSSMANN, W., LOTTATI, I. Review of propulsion applications and numerical simulations of the pulsed detonation engine concept. Journal of Propulsion and Power. 1991, 7(6), 857-865. https://doi.org/10.2514/3.23402

[9] EIDELMAN, S., GROSSMANN, W. Pulsed detonation engine: experimental and theoretical review. American Institute of Aeronautics and Astronautics Paper. 1992.

https://doi.org/10.2514/6.1992-3168 
[10] KAILASANATH, K. Review of propulsion application of detonation waves. American Institute of Aeronautics and Astronautics Journal. 2000, 38(9), 1698-1708. https://doi.org/10.2514/2.1156

[11] HINKEY, J.B., WILLIAMS, J.T., HENDERSON, S.E. et al. Rotary-valved, multiple-cycle, pulse detonation engine experimental demonstration. American Institute of Aeronautics and Astronautics Paper. 1997. https://doi.org/10.2514/6.1997-2746

[12] GUSTAVSSON, J., NORI, V., SEGAL, C. Inlet/engine interactions in an axisymmetric pulse detonation engine system. Journal of Propulsion and Power. 2003, 19(2), 282-286. https://doi.org/10.2514/2.6109

[13] RASHEED, A., GLASER, A., DUNTON, R.A. et al. Experimental and numerical investigation of a valved multi-tube PDE. 46th AIAA Aerospace Sciences Meeting and Exhibit. Reno 2008. https://doi.org/10.2514/6.2008-110

[14] MATSUOKA, K., ESUMI, M., KASAHARA, J. et al. Study on valve systems for pulse detonation engines. 46th $A I$ AA/ASME/SAE/ASEE Joint Propulsion Conference \& Exhibit. Nashville 2010. https://doi.org/10.2514/6.2010-6672

[15] SHIMO, M., HEISTER, S.D. Multicyclic-detonationinitiation studies in valveless pulsed detonation combustors. Journal of Propulsion and Power. 2008, 24(2), 336-344. https://doi.org/10.2514/1.29546

[16] PENG, C., FAN, W., ZHENG, L. et al. Experimental investigation on valves air-breathing dual-tube pulse detonation engines. Applied Thermal Engineering. 2012, 51(1-2), 11161123. https://doi.org/10.1016/j.applthermaleng.2012.10.026

[17] LU, J., ZHENG, L., WANG, Z. et al. Operating characteristics and propagation of back-pressure waves in a multi-tube two-phase valveless air-breathing pulse detonation combustor. Experimental Thermal and Fluid Science. 2015, 61, 12-23. https://doi.org/10.1016/j.expthermflusci.2014.10.010

[18] LU, J. Investigations on key technologies of the pulse detonation turbine engine. Northwestern Polytechnical University.

[19] RASHEED, A., TANGIRALA, V.E., VANDERVORT, C.L. et al. Interactions of a pulsed detonation engine with a $2 \mathrm{D}$ blade cascade. 42nd AIAA Aerospace Sciences Meeting and Exhibit. Reno 2004. https://doi.org/10.2514/6.2004-1207

[20] FROLOV, S.M. (ed.) Pulsed Detonation Engines. Torus Press. Moscow 2006.

[21] FROLOV, S.M., AKSENOV, V., IVANOV, V. et al. Catapult launching tests of an unmanned aerial vehicle with a ramjet pulsed detonation engine. European Conference for Aeronautics and Space Sciences. 2008. https://doi.org/10.13009/EUCASS2019-178

[22] DEAN, A.J., RASHEED, A., TANGIRALA, V.E. et al. Operation and noise transmission of an axial turbine driven by a pulse detonation combustor. Proceedings of International Gas Turbine Institute. ASME Turbo Expo 2005, 6, 12751284. https://doi.org/10.1115/GT2005-69141

[23] NORRIS, G. Pulse power: pulse detonation engine-powered flight demonstration marks milestone in Mojave. Aviation Week \& Space Technology. 2008, 168(7), 60.

[24] WOLAŃSKI, P. Detonation engines. Journal of KONES. 2011, 18(3), 515-521.

[25] WOLAŃSKI, P. Detonative propulsion. Proceedings of the Combustion Institute. 2013, 34(1), 125-158. https://doi.org/10.1016/j.proci.2012.10.005

[26] XIE, Q., JIA, Z., WENA, H. et al. Review on the rotating detonation engine and typical problems. Transaction on Aerospace Research. 2020, 4(261), 107-163. https://doi.org/10.2478/tar-2020-0024

[27] WOLAŃSKI, P. (ed.) Research on detonative propulsion in Poland. Wydawnictwa Naukowe Sieci Badawczej Łukasiewicz - Instytutu Lotnictwa. Warsaw 2021.
[28] NETTLETON, M.A. Gaseous Detonations: Their Nature, Effects and Control. Butterworths. London 1987.

[29] WOLAŃSKI, P. Rotating detonation wave stability. 23rd International Colloquium on the Dynamics of Explosions and Reactive Systems. Irvine 2011.

http://www.icders.org/ICDERS2011/abstracts/ICDERS2011 -0211.pdf

[30] XIE, Q., WEN, H., LI, W. et al. Analysis of operating diagram for H2/air rotating detonation combustors under lean fuel condition. Energy. 2018, 151, 408-419. https://doi.org/10.1016/j.energy.2018.03.062

[31] SUCHOCKI, J., YU, S.T., HOKE, J. et al. Rotating detonation engine operation. 50th AIAA Aerospace Sciences Meeting including the New Horizons Forum and Aerospace Exposition. Nashville 2012. https://doi.org/10.2514/6.2012-119

[32] YI, T-H., JING, L., TURANGAN, C. et al. Numerical study of detonation processes in rotating detonation engine and its propulsive performance. Transaction on Aerospace Research. 2020, 3(260), 30-48. https://doi.org/10.2478/tar-2020-0015

[33] KAWALEC, M., PERKOWSKI, W., WOLANSKI, P. Development of rocket engines with detonation combustion chamber. [In] Wolański, P. (ed.): Research on detonative propulsion in Poland. Wydawnictwa Naukowe Sieci Badawczej Eukasiewicz - Instytutu Lotnictwa. Warsaw 2021.

[34] BYKOVSKII, F.A., ZHDAN, S.A., VEDERNIKOV, E.F. Continuous spin detonations. Journal of Propulsion and Power. 2006, 22(6), 1204-1216. https://doi.org/10.2514/1.17656

[35] ANAND, V., GEORGE, A.S., DRISCOLL, R. et al. Characterization of instabilities in a rotating detonation combustor. International Journal of Hydrogen Energy. 2015, 40(46), 16649-16659. https://doi.org/10.1016/j.ijhydene.2015.09.046

[36] TANG, X.M., WANG, J.P., SHAO, Y.T. Three-dimensional numerical investigations of the rotating detonation engine with a hollow combustor. Combustion and Flame. 2015, 162(4), 997-1008. https://doi.org/10.1016/j.combustflame.2014.09.023

[37] FOTIA, M. Update on air breathing detonation driven propulsion research. International Workshop on Detonation for Propulsion. 2015.

[38] FOTIA, M., HOKE, J., SCHAUER, F. Experimental performance scaling of rotating detonation engines operated on gaseous fuels. Journal of Propulsion and Power. 2017, 33(5), 110. https://doi.org/10.2514/1.B36213

[39] HEISTER, S., SLABAUGH, C. et al. Advancing pressure gain combustion in terrestrial turbine systems. University Turbine Systems Research Workshop. 1004. 2016. https://www.netl.doe.gov/sites/default/files/2017-11/utsr25343-kickoff-presentation.pdf

[40] EUDE, Y., DAVIDENKO, D., FALEMPIN, F. et al. Use of the adaptive mesh refinement for $3 \mathrm{D}$ simulations of a CDWRE (continuous detonation wave rocket engine). 17th AIAA International Space Planes and Hypersonic Systems and Technologies Conference. San Francisco 2011. https://doi.org/10.2514/6.2011-2236

[41] DAVIDENKO, D., EUDE, Y., FALEMPIN, F. Numerical study on the annular nozzle optimization for rocket application. 16th AIAA/DLR/DGLR International Space Planes and Hypersonic Systems and Technologies Conference. Bremen 2009. https://doi.org/10.2514/6.2009-7390

[42] WOLAŃSKI, P., KALINA, P., BALICKI, W. et al. Development of Gasturbine with Detonation Chamber. Detonation Control for Propulsion, Pulse Detonation and Rotating Detonation Engines. Springer, Cham 2018.

https://doi.org/10.1007/978-3-319-68906-7_2 
[43] WOLAŃSKI, P., BALICKI, W., PERKOWSKI, W. et al. Experimental research of liquid-fueled continuously rotating detonation chamber. Shock Waves. 2021, 31, 807-812. https://doi.org/10.1007/s00193-021-01014-w

[44] FLOTTAU, J., DUBOIS, T. Airbus places big bet on hydrogen propulsion as aviation's future. Aviation Week and Space Technology. 2020, 25 September.

Michał Kawalec, DEng. - Aircraft Propulsion System Department, Łukasiewicz Research Network Institute of Aviation.

e-mail: michal.kawalec@ilot.lukasiewicz.gov.pl

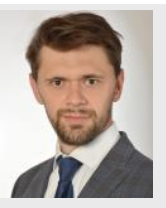

Borys Łukasik, DEng. - Aircraft Propulsion System Department, Łukasiewicz Research Network Institute of Aviation.

e-mail: borys.lukasik@ilot.lukasiewicz.gov.pl https://aviationweek.com/aerospace/programmanagement/airbus-places-big-bet-hydrogen-propulsionaviations-future

[45] WARWICK, G., NORRIS, G., DUBOIS, T. Drive to decarbonize aviation raises green hydrogen challenges. Aviation Week and Space Technology. 2020, 8 October.

https://aviationweek.com/special-topics/sustainability/drivedecarbonize-aviation-raises-green-hydrogen-challenges

Witold Perkowski, DEng. - Aircraft Propulsion System Department, Łukasiewicz Research Network - Institute of Aviation.

e-mail: witold.perkowski@ilot.lukasiewicz.gov.pl

Adam Bilar, MEng - Aircraft Propulsion System Department, Łukasiewicz Research Network Institute of Aviation.

e-mail: adam.bilar@ilot.lukasiewicz.gov.pl
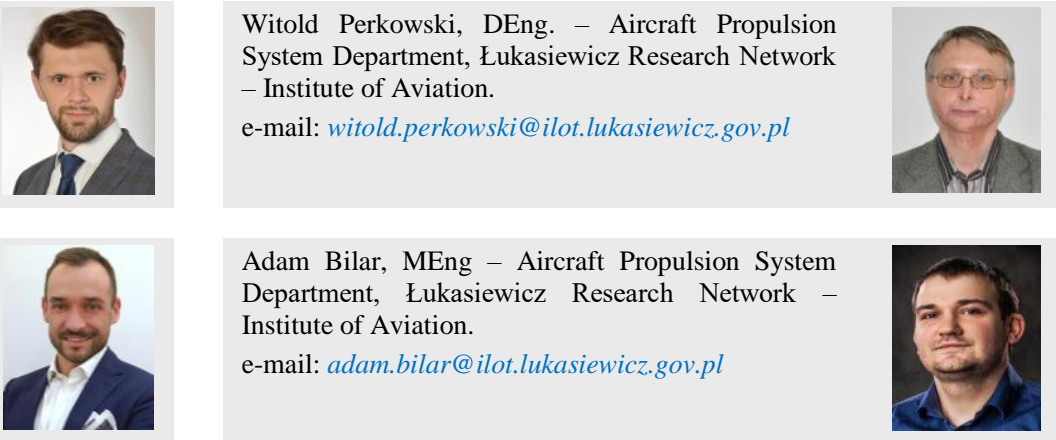

Prof. Piotr Wolański, DSc., DEng. - Łukasiewicz Research Network - Institute of Aviation.

e-mail:piotr.wolanski@ilot.lukasiewicz.gov.pl 